\title{
FOR KRITIKA KULTURA
}

\author{
Antony Tatlow \\ University of Dublin \\ atatlow@tcd.ie
}

You have asked me to contribute a short statement regarding my involvement as a member of the international board of editors in anecdote, or testimonial, or expression of support. As to why I was appointed, you should ask Lulu Torres Reyes. Perhaps I can give some sense of why I accepted.

I worked in the University of Hong Kong from 1965-1996 where I became Professor of Comparative Literature. Then I went to the University of Dublin (Trinity College) in the same position for ten years, and am now Honorary Professor in the Drama Department. I first visited Manila in 1966 to participate in a Seminar organized by the Association of Southeast Asian Institutions of Higher Learning (ASAIHL) on language problems in Southeast Asian universities. I edited the Proceedings, published in 1968, which covered topics from language learning to cultural communication, and the problems of language use in third level education. Fresh out of Europe, I was intrigued and alarmed by what I was seeing for the first time. Flying from Hong Kong, I sat beside a Philippine woman who unravelled some gauze bandage from her bag, to reveal an open razor blade, which she put on her knee and then produced a set of beads and recited the rosary during the flight. I wondered what that was telling me about my destination.

The next remarkable encounter was with Carlos Romulo, then President of the University of the Philippines and of ASAIHL whom I was placed beside at lunch hosted by the University. He joked about preserving all his faculties, suggested we probably would not succeed in solving the language problems in Southeast Asia, and took me into his study to admire the signed photographs of eminent world citizens on the walls from President Eisenhower down. Then, courtesy of the fact that the organizer of our conference was the engaging Professor of English at 
Chulalongkorn University, Prince Prem Purachatra, a cousin of the King, we met with Imelda Marcos in the Malacañang, where we heard of her Integrated Social Welfare Program for the Philippines, now in its initial phase. After this meeting we sat and drank fruit juice on the terrace and looked across the Pasig river at the private golf course on the other bank. We were handed a Message:

My deep concern for social welfare stems from the realization that a country's greatness is measured by the manner in which it takes care of its dependent groups: children and youth, the handicapped, the poor, the downtrodden, the aged and the infirm. Our dreams of a progressive nation cannot be fulfilled so long as the needy segment of our population remains neglected and abandoned. The resulting deterioration can offset any gains we may have made in the economic sector.

It is for this very reason that I am launching an integrated program for social welfare. The task of relieving distress and suffering so as to enable people to move towards higher goals is every individual's responsibility, the government's as well as the community's.

May I call on everyone who is able to give of themselves in the service of others to join me in this noble undertaking.

- Imelda Romualdez Marcos

Afterwards we were taken on a bus trip around Manila, past the Tondo rubbish dump, aka Smokey Mountain, to be shown a gated community-the real purpose of the journey-houses with gardens and lawns, surrounded by walls and guarded by Alsatian dogs. Asked what I thought of it, I replied it seemed to me a prerevolutionary situation.

Impressed by what I learnt, in spite of sometimes over whelming difficulties, about efforts to bring change to these circumstances, when President of the International Brecht Society, I invited the Philippine Educational Theater Association (PETA) to perform during the Society's $7^{\text {th }}$ Symposium in Hong Kong in 1986, its first and so far only meeting in Asia, at which Prof. Reyes spoke eloquently about Brecht in the Philippines. PETA performed excerpts from their visually gripping production of The Caucasian Chalk Circle adapted into Mindanao culture and made a deep impression on us all, both the imaginative performance and the personal qualities of the performers. In early 1987 I asked Jose Maria Sison to speak in the University of Hong Kong. Freed by the Aquino government, he had been offered a leading post in a political party but turned it down, arguing he needed time to reflect on what was happening and wanted to travel. He had been behind bars for ten years. The person who took the job was assassinated. So was his successor.

Later that year on the way to Australian National University in Canberra to attend conferences on cultural relations between the Orient and the Occident, I gave some talks at Ateneo de Manila University and the University of the Philippines, 
and also saw the first exhibition of socially critical art in the grandiose Cultural Center of the Philippines, where Nick Tiongson told me about the new cultural priorities, and was discovering how very difficult it was to achieve anything outside the Center that had been handed to them.

In a room upstairs, they had arranged one of the most moving exhibitions I have seen in any gallery. You passed through a door and set against the wall to left and right were rows of silent lighted candles. The wide wall opposite was covered from top to bottom with hundreds of narrow overlapping strips of white paper. An abstraction? The aesthetics of poverty? Not exactly. On each short strip was written in black ink the name of one person who had disappeared during the years of the Marcos regime.

Those who worked in the countryside to help benignly neglected people understand their problems and the history of their country, its specific articulation in the encounter between Orient and Occident in the global flow of forces, came face to face with this complexly structured, and then internalized diffusion of power. However sophisticated your description, for them the reality was harsh. The landlords didn't like them. They ran the very real risk of being shot. It had happened to some recently, at the hands of "self-defence" neighborhood goon squads organized by the military. In the Philippines, I learnt, they called it "salvaging."

In a report on the subsequent Canberra conferences for the Asian Studies Association of Australia Review, I remarked that there was no representation from the Philippines and no discussion of its problems. I made clear my respect for the people I met in and from the Philippines and my sympathy for the real problems they faced, beyond anything I had otherwise encountered.

Maybe some of this explains why I was asked to join the international board of $K K$, but I really don't know. 